ISSN 1392-3196 / e-ISSN 2335-8947

Zemdirbyste-Agriculture, vol. 100, No. 4 (2013), p. 349-354

DOI 10.13080/z-a.2013.100.044

\title{
The effect of meadow phytocenoses productivity and herbage quality on the energy value of biomass
}

\author{
Regina SKUODIENE ${ }^{1}$, Regina REPŠIENE' ${ }^{1}$, Danute KARČAUSKIENÉ ${ }^{1}$, \\ Kazimieras KATUTIS ${ }^{1}$, Egle SENDŽIKIENE ${ }^{2}$ \\ ${ }^{1}$ Vèžaičiai Branch, Lithuanian Research Centre for Agriculture and Forestry \\ Gargždų 29, Vėžaičiai, Klaipèda distr., Lithuania \\ E-mail: rskuod@vezaiciai.lzi.lt \\ ${ }^{2}$ Aleksandras Stulginskis University \\ Studentų 11, Akademija, Kaunas distr., Lithuania
}

\begin{abstract}
A high proportion of Lithuania's meadows are either in poor condition or abandoned (not mowed and not grazed). These changes in meadow use have negative consequences such as increasing area of meadows not being used and landscape turning wild, which inevitably deteriorate their ecological value.

Research was done during 2009-2012 in five habitats, two of which are non-flooded relatively abandoned meadows of undulating relief and three flooded meadows, present in the riverside, central and pre-land parts of the Nemunas delta. The study was aimed to compare the influence of the productivity and quality of the phytocenoses of non-flooded and flooded meadows on the energy value of their biomass. The productivity and energy value of meadow swards depend on the habitat's ecological conditions, which form different habitations. The average dry matter content of the non-flooded meadows was $4.19 \mathrm{t} \mathrm{ha}^{-1}$ and that of flooded meadows $6.03 \mathrm{t} \mathrm{ha}^{-1}$ ( $31 \%$ higher). The quality of biomass formed in different habitats was similar. Dry matter contained $6.69-9.75 \%$ crude protein, $23.81-25.56 \%$ crude fibre, $1.70-2.29 \%$ crude fat, $4.98-5.98 \%$ crude ash, $44.40-47.20 \%$ organic carbon $\left(\mathrm{C}_{\text {org }}\right)$, $1.26-1.44 \%$ total nitrogen $\left(\mathrm{N}_{\text {total }}\right)$, and $0.12-0.16 \%$ sulphur. The swards of the non-flooded meadows accumulated slightly higher contents of potassium (on average $1.66 \%$ ), while those of flooded meadows accumulated higher concentrations of calcium (on average $0.70 \%$ ). The net calorific value of grasses of different meadows varied from 16.63 to $16.88 \mathrm{MJ} \mathrm{kg}^{-1}$ and energy potential from 60.73 to $143.8 \mathrm{GJ} \mathrm{ha}^{-1}$. The energy potential of the sward of the flooded meadow, present in the central part of the Nemunas delta was significantly higher (143.8 GJ), it accumulated 1.8-2.4 and 1.6-2.2 times more energy compared with non-flooded or other flooded meadows. The energy input for the preparation and transportation of herbage from the meadows under investigation totalled 2.8 $\mathrm{GJ} \mathrm{ha}^{-1}$. The highest content of useful energy $\left(141.03 \mathrm{GJ} \mathrm{ha}^{-1}\right)$ was obtained from the flooded meadow, present in the central part of the Nemunas delta. Other meadows demonstrated similar final energy contents: meadows in the riverside of the Nemunas delta $-89.01 \mathrm{GJ} \mathrm{ha}^{-1}$, non-flooded meadows, present in the lower terrain of undulating relief - 77.56 GJ ha-1, meadows of the pre-land Nemunas delta $-62.88 \mathrm{GJ}^{-1} \mathrm{ha}^{-1}$, non-flooded meadows, present in the upper terrain of undulating relief - $57.93 \mathrm{GJ} \mathrm{ha}^{-1}$.
\end{abstract}

Key words: ecological conditions, energy value, meadow phytocenoses, productivity, sward quality.

\section{Introduction}

Perennial grasses can be used as forage and as a protection measure against soils erosion. They can also serve as a feedstock for energy production. When grown for biofuel, perennial grasses are superior to short-rotation trees because of their ability to yield in the first year after sowing and to be harvested for a long time without being reseeded. This is especially characteristic of natural and semi-natural meadow ecosystems where perennial grasses re-seed naturally. Perennial grasses measure up to shortrotation woody plants by the biomass yield and are less demanding in terms of nutrients (Šiaudinis, 2010). Other advantages of perennial swards are that it is easy to change their use and that common agricultural technologies and machinery can be employed for their management and harvesting (Kryževičienè et al., 2005). Hasselmann and Bergmann (2007) have indicated that the use of biomass from the extensively and intensively managed meadows growing in the protected areas will be of great significance for future energy production in Germany. Researchers from Hungary and the United States have also suggested a possibility of meadow biomass utilisation for energy production (Orosz et al., 2008).
The chemical composition of solid biofuels (as defined in Directive 2000/76/EC and CEN/TC 335-WG2 N94) has manifold effects on their thermal utilisation. The elements $\mathrm{C}, \mathrm{H}$ and $\mathrm{O}$ are the main components of solid biofuels and are of special relevance for the gross calorific value, $\mathrm{H}$ in addition also for the net calorific value. Individual chemical elements have a different effect on the biofuel production process (Obernberger et al., 2006). Particularly high concentrations of $\mathrm{K}, \mathrm{Cl}$ and $\mathrm{N}$ are a limiting factor for this solid fuel utilisation (Tonn et al., 2010). The concentration of elements in the biomass varies at different stages of development. The contents of $\mathrm{K}, \mathrm{Ca}, \mathrm{N}$ and $\mathrm{S}$ in dry matter are highly dependent on the timing of cut, i.e. when the cut is taken in the autumn, these elements occur at higher concentrations compared with the cut taken early in spring (Richter, 2010; Ricter et al., 2010). When extensively managed swards were cut on a monthly basis during the June-September period, the contents of $\mathrm{N}, \mathrm{S}, \mathrm{Cl}$, $\mathrm{K}$ and $\mathrm{Ca}$ in the biomass met the desirable levels in none of the cases (Obernberger, 1998). This leads to the conclusion that the time of cut should be chosen in compliance with the environmental protection requirements (Tonn et al., 2008). 
In Lithuania, different-aged meadows that have not been fertilised and re-seeded for more than a decade account for a large proportion of the abandoned land. This has both positive and negative consequences. Vegetation becoming more natural and increasing species diversity are the positive aspects; however, abandoned land raises a lot of concern because of the spread of persistent weeds, shrubs and trees. Costly land reclamation systems deteriorate because of neglect and mismanagement. The use of seminatural meadows of the Nemunas delta has changed with the changes in economic conditions of Lithuania. Two stages could be distinguished: 1) 1960-1989, active reclamation and restoration, which dramatically altered the unique landscape of the region and 2) since 1990, extensive use (discontinued grass meal production, meadows are less or not fertilised at all, not grazed and not cut) leads to the occurrence of renaturalization process. Because of the changes in land use it is necessary to assess the state of semi-natural meadows, taking into account the history of their use and to envisage future prospects, one of which is the use of biomass formed by meadow phytocenoses for bio-energy production.

The objective of the present work was to compare the effect of the productivity and quality of phytocenoses of non-flooded and flooded meadows on energy value.

\section{Materials and methods}

Description of the experimental site. Research was done during the period 2009-2012. Two nonflooded relatively neglected meadows and three flooded meadows, present in the riverside, central and pre-land parts of the Nemunas delta were chosen.

The Jurjonai (Klaipèda distr.) experimental site was established in a non-flooded meadow on the higher terrain of undulating relief. The soil of the experimental site is Dystric Albeluvisol $(A B d)$. The agrochemical characteristics were as follows: $\mathrm{pH}_{\mathrm{KCl}}-4.8$, mobile $\mathrm{P}_{2} \mathrm{O}_{5}$ and $\mathrm{K}_{2} \mathrm{O}-51$ and $86 \mathrm{mg} \mathrm{kg}^{-1}$ soil, respectively, total nitrogen $\left(\mathrm{N}_{\text {tota }}\right)-0.146 \%$, organic carbon $\left(\mathrm{C}_{\text {org }}\right)-1.69 \%$ and a humus layer of about $20 \mathrm{~cm}$. Ground water during the vegetation season is deeper than $1.2 \mathrm{~m}$. Prior to the establishment of the experimental site, farming activities had not been performed for about five years. During the test period, one cut was taken during plant vegetation period (20-30 June) and one grazing was performed at the end of August.

Grikštaičiai (Klaipèda distr.) experimental site was established in a non-flooded meadow on the lower terrain of undulating relief. The soil of the experimental site is Haplic Luvisol $(L V h)$. The agrochemical characteristics were as follows: $\mathrm{pH}_{\mathrm{KCl}}-5.2$, mobile $\mathrm{P}_{2} \mathrm{O}_{5}$ and $\mathrm{K}_{2} \mathrm{O}-67$ and $181 \mathrm{mg} \mathrm{kg}^{-1}$ scl soil, respectively, $\mathrm{N}_{\text {total }}-0.288 \%, \mathrm{C}_{\text {org }}-2.85 \%$ and a humus layer of about $20 \mathrm{~cm}$. The depth to ground water in the first half of the vegetation period (until 1 July) is one meter, and later when precipitation rate increases it rises and varies within a range of $0.5-0.7 \mathrm{~m}$. During the non-vegetation season the ground water rises close to the soil surface. Prior to the establishment of the experimental site, management activities had not been performed for about five years. During the test period, one cut was taken during plant vegetation period (25-28 June or 1 July).

Tulkiaragè (Tulkiaragè polder, Šilutè distr.) experimental site was established in the riverside part of the Nemunas delta behind a levee. The soil of the experimental site is Areni-Calcicaric Fluvisol (FLc-ar). The agrochemical characteristics were as follows: $\mathrm{pH}_{\mathrm{KCl}}$ - 6.9, mobile $\mathrm{P}_{2} \mathrm{O}_{5}$ and $\mathrm{K}_{2} \mathrm{O}-154$ and $69 \mathrm{mg} \mathrm{kg}^{-1}$ soil, respectively, $\mathrm{N}_{\text {total }}^{2}-0.261 \%, \mathrm{C}_{\text {org }}-2.53 \%$ and a humus layer of 1 meter and deeper. During the vegetation period the depth to ground water was $1.5 \mathrm{~m}$. Flood period is short 10-20 days, but flooding occurs annually. During the test period, one cut was taken during plant vegetation period (25 June - 1 July).

Šyša-1 (Šyša polder, Šilute distr.) experimental site was established in the pre-land part of the Nemunas delta. The soil of the experimental site is Endohipogleyi-Calcicaric Fluvisol $(F L c-g l n-w)$. The agrochemical characteristics were as follows: $\mathrm{pH}_{\mathrm{KCl}}-5.5$, mobile $\mathrm{P}_{2} \mathrm{O}_{5}$ and $\mathrm{K}_{2} \mathrm{O}-111$ and $83 \mathrm{mg} \mathrm{kg}^{-1}$ soil, respectively, $\mathrm{N}_{\text {total }}-0.221 \%, \mathrm{C}_{\text {org }}-2.34 \%$ and a humus layer of about $60 \mathrm{~cm}$. Ground water level during the vegetation period varies depending on the performance of the pump-house but does not reach deeper than 1 meter. The flood period is medium-long up to one month. During the test period, one cut was taken during plant vegetation period (2 or 26-28 August).

Šyša-2 (Syša polder, Šilute distr.) experimental site was established in the central part of the Nemunas delta. The soil of the experimental site is Terric Histosol $(H S s)$. The agrochemical characteristics were as follows: $\mathrm{pH}_{\mathrm{KCl}}-5.9$, mobile $\mathrm{P}_{2} \mathrm{O}_{5}$ and $\mathrm{K}_{2} \mathrm{O}-59$ and $96 \mathrm{mg} \mathrm{kg}^{-1}$ soil, respectively, $\mathrm{N}_{\text {total }}-0.388 \%, \mathrm{C}_{\text {org }}-3.69 \%$. Peat layer was about $60 \mathrm{~cm}$. Ground water level during plant vegetation period varies also depending on the performance of the pump-house, but does not reach deeper than half a meter. The flood period is long - up to two months. During the test period, one cut was taken during plant vegetation period ( 2 or 26-28 August).

The timing of the cut of meadows was adjusted to that of farmers who adhere to the requirements of Rural Development Programme's "Management of natural and semi-natural meadows"; "Natura 2000" as well as the regulations of the regional park of the Nemunas delta, which allow cuts to be taken only after 15 June and in specific areas of ornithological reserves only after 1 July. All meadows had not been fertilised for five and more years. Dry matter yield was determined by cutting $1 \mathrm{~m}^{2}$ plots (6 replications) in the experimental site. A sample of $0.5 \mathrm{~kg}$ fresh plant mass was taken from each replication for the determination of dry matter yield. Dry matter content was measured by drying plant samples at $105^{\circ} \mathrm{C}$ to the constant weight. Completely dried plants were weighed and dry matter content was calculated. Plant chemical analyses were made using the following methods: $\mathrm{N}_{\text {total }}, \mathrm{C}_{\text {org }}$ and sulphur (S) concentrations by Dumas method (DIN/ISO 13878), potassium (K) and calcium $(\mathrm{Ca})$ contents by flame photometry, crude protein - according to nitrogen content, i.e. by multiplying it by a coefficient of 6.25 (Directive 72/199/EEC); crude fat by Soxleto instrument after Ruškovski (Directive 71/393/ EEC); crude fibre by Kurshner-Hanek method (Directive 73/46/EEC); crude ash by combustion and weight method (Directive 71/250/EEC). The energy potential of swards was calculated according to biomass yield expressed in dry matter and net calorific value: $E_{p}=D \times Q_{g}$, where $E_{p}-$ energy potential of the sward $\mathrm{GJ} \mathrm{ha}^{-1}, \mathrm{D}$ - biomass content $\mathrm{t} \mathrm{ha} \mathrm{h}^{-1}$ of the sward, $\mathrm{Q}_{\mathrm{g}}$ - net calorific value of biomass $\mathrm{MJ} \mathrm{kg}^{-1}$. Calorific value was measured using a calorimeter IKA C2000. The measurements met the requirements of the ISO 1928 standards. The weight of a sample was 1.0 $1.5 \mathrm{~g}$. Soil agrochemical characteristics in the $0-20 \mathrm{~cm}$ soil layer were determined before trial establishment using the following methods: $\mathrm{pH}_{\mathrm{KCl}}$ by electrometric method, available $\mathrm{P}_{2} \mathrm{O}_{5}$ and $\mathrm{K}_{2} \mathrm{O}$ by A-L method, $\mathrm{N}_{\text {total }}$ by Kjeldahl, and $\mathrm{C}_{\text {org }}$ by a mineraliser "Heraeus" (Germany).

Meteorological conditions differed between the experimental years; however, they were favourable for the development of perennial grasses. Very good growth conditions for perennial grasses were in non-flooded meadows, which in all experimental years during the vegetation period received a rainfall amount of 580.3 $698.3 \mathrm{~mm}$, which was 1.1-1.3 times more than the longterm mean. The plants of the flooded meadows received 
$459.0-660.0 \mathrm{~mm}$ rainfall during the vegetation period. In 2009 , the amount of rainfall was below the long-term mean, and in 2010-2012 the amount of rainfall made up $1.1-1.3$ of the long-term mean.

All the meadows under investigation were cut only once, no fertilisers were used, therefore the energy input per hectare for technological operations (biomass harvesting and preparation) were the same and amounted to $2.8 \mathrm{GJ} \mathrm{ha}^{-1}$ (Jasinskas, Zvicevičius, 2008). When calculating energy input, it was assumed that meadow productivity was similar.

Statistical analysis was done using the statistical data processing software package SELEKCIJA (software ANOVA, STAT) (Tarakanovas, Raudonius, 2003).

\section{Results and discussion}

The productivity of meadow phytocenoses. Diverse ecological conditions form different phytocenoses of meadows. Averaged data showed that over four years flooded meadows produced $6.03 \mathrm{t} \mathrm{ha}^{-1}$ or $31 \%$ higher dry matter content compared with non-flooded meadows (Fig.). This was associated with the content of biogenic elements in the soil. Floodplain soils were found to contain higher concentrations of $\mathrm{N}_{\text {total }}$ and organic matter compared with mineral soils. A strong $\left(r=0.777^{* *}\right.$ and $\left.0.692^{*}\right)$ correlation was established between dry matter content and soil $\mathrm{N}_{\text {total }}$ and organic matter content.

In all experimental years, the flooded meadow Šyša-2, present in the central part of the Nemunas delta produced significantly higher (from 7.09 to $10.55 \mathrm{t} \mathrm{ha}^{-1}$ ) dry matter yield. The higher productivity potential of this meadow was determined by favourable moisture regime and nutrient-rich soil. The flooded meadow Tulkiarage, which is present in the riverside part of the Nemunas delta was characterised by satisfactory yields $(7.20 * *$ and $6.42 * * \mathrm{t} \mathrm{ha}^{-1}$ ) in 2010 and 2011. This might have also been influenced by rainier plant vegetation periods. The average dry matter yield of non-flooded meadows was $4.19 \mathrm{t} \mathrm{ha}^{-1}$. In all experimental years, a higher dry matter content (4.33-5.51 t ha-1) was noted for the Grikštaičiai non-flooded meadow present in the area of lower relief and characterised by a higher humus content $\left(\mathrm{C}_{\mathrm{org}}-2.85 \%\right)$ and in which phytocenose less demanding in terms of natural conditions had formed. Other researchers obtained similar findings in different geographical terrains. In Germany, dry matter content of swards varies from 1.9 to $9.5 \mathrm{t} \mathrm{ha}^{-1}$ (Hensgen et al., 2012), in semi-natural meadows - from 4.0 to $12.0 \mathrm{t} \mathrm{ha}^{-1}$ (Thumm, Tonn, 2010), in mountainous terrains - 3.4-5.8 $\mathrm{t} \mathrm{ha}^{-1}$ (Wachendorf et al., 2009). In Great Britain, unfertilised meadows produce $1.5-6.0$ tha $^{-1}$ dry matter (Tallowin, Jefferson, 1999), and in Wales the dry matter content varies within a wider range from 1.3 to $11.0 \mathrm{t} \mathrm{ha}^{-1}$ (Hensgen et al., 2012).

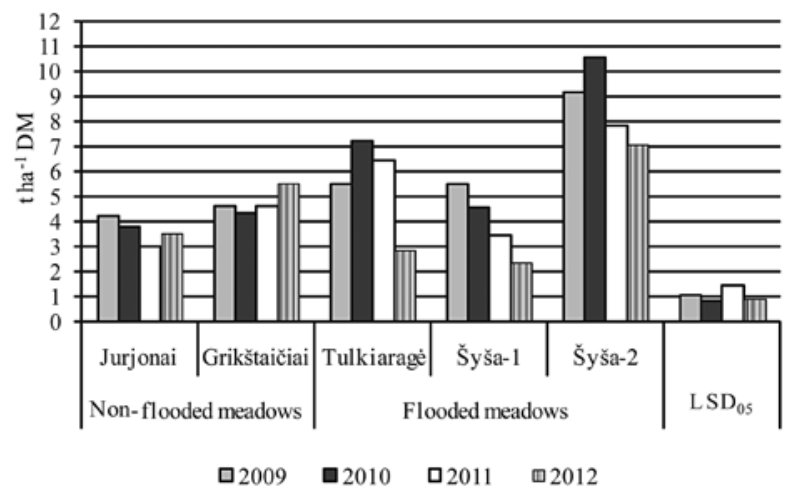

Figure. Dry matter (DM) yield variation in various habitats in 2009-2012
Chemical composition of biomass of swards. The quality of grasses differs depending on the meteorological conditions of the growing year, grass species diversity (Butkute, Paplauskienė, 2006; Tilvikienè, 2012), plant development stage (Butkutè, Paplauskienè, 2004). The dry matter of high-quality meadow herbage which can optimally meet the needs of productive livestock contains $16-22 \%$ crude fibre, $12.5-15.0 \%$ crude protein, $2.5-3.5 \%$ crude fat, and 6-8\% crude ash (Апените, Латвиетис, 1983). For herbage biomass used as feedstock for biofuel production, an important indicator is the content of fibre, which is composed of cellulose, hemicellulose and lignin because they are the main combustible materials that govern combustion quality of biofuel (Scholz, Berg, 1998). The data averaged over the four years suggest that the dry matter of the phytocenoses formed in different habitats contained $6.69-9.75 \%$ crude protein, $23.81-25.56 \%$ crude fibre, $1.70-2.29 \%$ crude fat and $4.98-5.98 \%$ crude ash (Table 1 ). The obtained differences were within the error range. Dry matter percentage varied from $89.16 \%$ to $91.05 \%$.

Since Fabaceae family plants accounted for a small proportion (from $1.3 \%$ to $13.6 \%$ ) in the phytocenoses of meadows, the contents of crude protein established were also low. The highest concentrations of crude protein were accumulated by the grasses of the flooded meadows, present in the pre-land part of the Nemunas delta while the lowest concentrations were measured for the grasses of the flooded meadow Šyša-2, present in the central part of the Nemunas delta. The coefficient of variation of crude protein values was low (5.60-9.89\%), except for the Šyša-2 meadow, where it was $27.17 \%$. The highest concentrations of crude fibre $(25.56 \%)$ were accumulated by the grasses of flooded meadows, present in the central part of the Nemunas delta, while the lowest crude fibre concentrations were measured for the grasses of the flooded meadow Šyša-1, present in the pre-land part of the Nemunas delta. The variation coefficient of crude fibre values for all grasses was low $(1.37-6.61 \%)$. The percentage of fibre in dry matter is highly dependent on the maturity of the sward at the time of cutting. With increasing age of grass stems the content of fibre in the biomass increased and in September it made up 35-49\%, while the biomass of the sward left over winter and cut in spring contained the highest concentration of fibre, measuring $41-51 \%$ (Kryževičienė et al., 2005). On average, the highest crude fat concentration $(2.29 \%)$ was established in the herbage of both non-flooded meadows. A moderate variation of these indicators was estimated and the higher variation coefficient in Grikštaičiai meadow indicates that this sward, in terms of the parameter discussed is more diverse. The variation coefficient of crude fat values for all flooded meadows was low (2.39-9.91\%). Inappreciably more $(5.98 \%)$ crude ash was accumulated by the grasses of the flooded Tulkiarage meadow, present in the riverside part of the Nemunas delta, while the lowest concentration $(4.98 \%)$ was recorded for non-flooded Grikštaičiai meadow present in the lower relief terrain. For all swards, the variation coefficient of crude ash values was moderate (10.48-19.56\%). The qualities of bioefuel are most markedly influenced by six main elements $(\mathrm{C}, \mathrm{H}$, $\mathrm{O}, \mathrm{N}, \mathrm{S}, \mathrm{Cl})$ and eight other elements $(\mathrm{Si}, \mathrm{Al}, \mathrm{Ca}, \mathrm{K}, \mathrm{Mg}$, $\mathrm{Na}, \mathrm{P}, \mathrm{Fe}$ ). The main elements influence energy qualities of fuel and other elements affect the characteristics of combustion products (McKendry, 2002; Obernberger et al., 2006). According to standard LST CEN/TS 14961-1:2010, in the biomass of unprocessed herbage (hay) the values of the main elements are as follows: $\mathrm{C}-49.0, \mathrm{H}-6.3, \mathrm{O}-$ $3.0, \mathrm{~N}-1.4, \mathrm{~S}-0.2, \mathrm{Cl}-0.8$ expressed in percentage from the combustible mass.

According to the data averaged over four years, the dry matter of phytocenoses formed in different 
Table 1. Average values \pm SE $(\%)$ of the quality indicators of plants of different meadows and coefficients of variation $(\mathrm{CV} \%)$

Data averaged over the period 2009-2012

\begin{tabular}{|c|c|c|c|c|c|}
\hline \multirow{2}{*}{ Parameter } & \multirow{2}{*}{ Dry matter } & \multicolumn{4}{|c|}{ Organic matter } \\
\hline & & crude protein & crude fibre & crude fat & crude ash \\
\hline & \multicolumn{5}{|c|}{ Jurjonai } \\
\hline $\begin{array}{c}\text { Average } \\
\text { CV\% }\end{array}$ & $\begin{array}{c}90.88 \pm 0.85 \\
1.87\end{array}$ & $\begin{array}{c}7.49 \pm 0.27 \\
7.23\end{array}$ & $\begin{array}{c}25.13 \pm 0.17 \\
1.37 \\
\end{array}$ & $\begin{array}{c}2.29 \pm 0.12 \\
10.5 \\
\end{array}$ & $\begin{array}{c}5.60 \pm 0.43 \\
15.28 \\
\end{array}$ \\
\hline & \multicolumn{5}{|c|}{ Grikštaičiai } \\
\hline $\begin{array}{c}\text { Average } \\
\text { CV\% }\end{array}$ & $\begin{array}{c}91.01 \pm 0.72 \\
1.58\end{array}$ & $\begin{array}{c}7.55 \pm 0.21 \\
5.60 \\
\end{array}$ & $\begin{array}{c}24.21 \pm 0.72 \\
5.98\end{array}$ & $\begin{array}{c}2.29 \pm 0.23 \\
19.9 \\
\end{array}$ & $\begin{array}{c}4.98 \pm 0.28 \\
11.33 \\
\end{array}$ \\
\hline \multicolumn{6}{|c|}{ Tulkiaragè } \\
\hline $\begin{array}{c}\text { Average } \\
\text { CV } \%\end{array}$ & $\begin{array}{c}91.05 \pm 0.58 \\
1.27 \\
\end{array}$ & $\begin{array}{c}8.12 \pm 0.40 \\
9.89 \\
\end{array}$ & $\begin{array}{c}24.83 \pm 0.82 \\
6.61 \\
\end{array}$ & $\begin{array}{c}2.21 \pm 0.03 \\
2.39 \\
\end{array}$ & $\begin{array}{c}5.98 \pm 0.43 \\
14.46 \\
\end{array}$ \\
\hline & \multicolumn{5}{|c|}{ Šyša-1 } \\
\hline $\begin{array}{c}\text { Average } \\
\text { CV\% }\end{array}$ & $\begin{array}{c}89.16 \pm 0.44 \\
0.99\end{array}$ & $\begin{array}{c}9.75 \pm 0.27 \\
5.62 \\
\end{array}$ & $\begin{array}{c}23.81 \pm 0.20 \\
1.69 \\
\end{array}$ & $\begin{array}{c}2.09 \pm 0.03 \\
2.98\end{array}$ & $\begin{array}{c}5.75 \pm 0.30 \\
10.48 \\
\end{array}$ \\
\hline & \multicolumn{5}{|c|}{ Šyša-2 } \\
\hline $\begin{array}{c}\text { Average } \\
\text { CV\% }\end{array}$ & $\begin{array}{c}89.65 \pm 0.53 \\
1.19\end{array}$ & $\begin{array}{c}6.69 \pm 0.91 \\
27.17\end{array}$ & $\begin{array}{c}25.56 \pm 0.42 \\
3.32\end{array}$ & $\begin{array}{c}1.70 \pm 0.08 \\
9.91\end{array}$ & $\begin{array}{c}5.16 \pm 0.50 \\
19.56\end{array}$ \\
\hline Average of the experiment & 90.35 & 7.92 & 24.71 & 2.12 & 5.49 \\
\hline $\mathrm{LSD}_{05}$ & 0.831 & 0.963 & 0.991 & 0.234 & 0.706 \\
\hline
\end{tabular}

habitats contained: $1.26-1.44 \% \quad \mathrm{~N}_{\text {total }}, 44.40-47.20 \%$ $\mathrm{C}_{\text {org }}$, and $0.12-0.16 \% \mathrm{~S}$ (Table 2). The differences of the mentioned indicators were within error range. The variation coefficient was small only for $\mathrm{C}_{\mathrm{org}}$.

The higher the carbon concentration in the biofuel, the higher its heat of combustion is (Malaták, Passian, 2011). The highest $C_{\text {org }}$ concentration was established in the sward of flooded Syša-2 meadow in the central part of the Nemunas delta, while the lowest concentration in Šyša-1 meadow in the pre-land part of the Nemunas delta. Potassium content established in the dry matter yield ranged from $1.25 \%$ to $1.76 \%$, significantly highest $\mathrm{K}$ content was determined in the herbage of non-flooded Grikštaičiai meadow, present in the lower relief area. Calcium contents in dry matter ranged from $0.48 \%$ to $0.85 \%$ and its highest contents were measured in the herbage of Šyša-1 meadow in the pre-land part of the Nemunas delta. Legumes increase $\mathrm{Ca}$ concentrations and, at the same time, increase N concentrations (Khalsa, 2013). In the Šyša-1 meadow in the pre-land part of the Nemunas delta the content of legumes was 1.2 times higher than that in non-flooded meadow, present in the higher terrain of undulating relief (Jurjonai), 4.4 times higher than that in Šyša-2 meadow in the central part of the Nemunas delta and 6.5 times higher than in the non-flooded meadow in the lower terrain of undulating relief (Grikštaičiai). The swards of non-flooded meadows accumulated slightly more $\mathrm{K}$, while those of flooded meadows accumulated more $\mathrm{Ca}$.

Table 2. Average values \pm SE (\%) of the chemical composition of plants of different meadows and coefficients of variation $(\mathrm{CV} \%)$

Data averaged over the period 2009-2012

\begin{tabular}{|c|c|c|c|c|c|}
\hline \multirow{2}{*}{ Parameter } & $\mathrm{N}_{\text {total }}$ & $\mathrm{C}_{\text {org }}$ & $\mathrm{S}$ & $\mathrm{K}$ & $\mathrm{Ca}$ \\
\hline & & & Jurjonai & & \\
\hline $\begin{array}{c}\text { Average } \\
\mathrm{CV} \%\end{array}$ & $\begin{array}{c}1.44 \pm 0.17 \\
23.75\end{array}$ & $\begin{array}{c}46.7 \pm 0.88 \\
3.78\end{array}$ & $\begin{array}{c}0.14 \pm 0.02 \\
34.43\end{array}$ & $\begin{array}{c}1.55 \pm 0.07 \\
9.35\end{array}$ & $\begin{array}{c}0.53 \pm 0.18 \\
66.10\end{array}$ \\
\hline & & & $\begin{array}{l}\text { Grikštaičiai } \\
\end{array}$ & & \\
\hline $\begin{array}{l}\text { Average } \\
\text { CV\% }\end{array}$ & $\begin{array}{l}1.36 \pm 0.06 \\
9.54\end{array}$ & $\begin{array}{c}46.3 \pm 0.09 \\
0.39\end{array}$ & $\begin{array}{l}0.14 \pm 0.01 \\
13.93\end{array}$ & $\begin{array}{c}1.76^{* * \pm 0} * 0.11 \\
13.00\end{array}$ & $\begin{array}{c}0.48 \pm 0.15 \\
63.12\end{array}$ \\
\hline & & & Tulkiaragè & & \\
\hline $\begin{array}{c}\text { Average } \\
\text { CV\% }\end{array}$ & $\begin{array}{c}1.35 \pm 0.08 \\
11.40\end{array}$ & $\begin{array}{c}46.0 \pm 0.15 \\
0.64\end{array}$ & $\begin{array}{c}0.13 \pm 0.01 \\
17.68\end{array}$ & $\begin{array}{c}1.36 \pm 0.09 \\
13.40\end{array}$ & $\begin{array}{c}0.66 \pm 0.12 \\
37.74\end{array}$ \\
\hline & & & Šyša-1 & & \\
\hline $\begin{array}{c}\text { Average } \\
\text { CV\% }\end{array}$ & $\begin{array}{c}1.36 \pm 0.08 \\
11.12 \\
\end{array}$ & $\begin{array}{c}44.4 \pm 0.47 \\
2.12\end{array}$ & $\begin{array}{c}0.16 \pm 0.01 \\
3.85\end{array}$ & $\begin{array}{c}1.26 \pm 0.06 \\
9.10\end{array}$ & $\begin{array}{c}0.85^{* *} \pm 0.11 \\
24.91\end{array}$ \\
\hline & & & Šyša-2 & & \\
\hline $\begin{array}{c}\text { Average } \\
\text { CV\% }\end{array}$ & $\begin{array}{c}1.26 \pm 0.19 \\
30.42 \\
\end{array}$ & $\begin{array}{c}47.2 \pm 0.99 \\
4.21\end{array}$ & $\begin{array}{c}0.12 \pm 0.01 \\
22.25\end{array}$ & $\begin{array}{c}1.25 \pm 0.09 \\
14.59 \\
\end{array}$ & $\begin{array}{c}0.60 \pm 0.13 \\
73.72 \\
\end{array}$ \\
\hline Average of the experiment & 1.35 & 46.11 & 0.14 & 1.44 & 0.62 \\
\hline $\mathrm{LSD}_{05}$ & 0.258 & 1.193 & 0.029 & 0.173 & 0.109 \\
\hline
\end{tabular}

Energy potential of the sward. Energy potential was calculated according to the productivity of swards and calorific value of their biofuel (calorific value is energy obtained having burnt $1 \mathrm{~kg}$ of solid fuel). Energy potential of swards is mostly determined by their productivity, which is governed by sward species composition, cutting time and meteorological conditions (Kryževičienè et al., 2005). Extensive meadow cut has an energy content of approximately 17-19 MJ kg-1 DM which can be utilized through combustion (Khalsa, 2013). The results of the calorific value of grass biofuel are provided in Table 3. The net calorific value of grasses growing in different habitats of meadows varied from 16.63 to $16.88 \mathrm{MJ} \mathrm{kg}^{-1}$. The differences obtained were within the error range. The variation coefficient of net calorific value was low (1.47-2.62\%) for all swards. Literature sources indicate that in order to achieve as high as possible calorific value of biofuel the swards intended for energy purposes need to be cut when plants have accumulated the highest fibre contents (Kryževičienè et al., 2005; Fang et al., 2013). In our study, the dry matter of phytocenoses that formed in different habitats contained $23.81-25.56 \%$ crude fibre (Table 2). The energy potential of meadow swards varied from 60.73 to $143.8 \mathrm{GJ} \mathrm{ha}^{-1}$. The energy potential of Šyša-2 meadow in central part of the Nemunas delta was significantly higher (143.8 GJ) compared with the average of the experiment, it was by $1.8-2.4$ and $1.6-2.2$ times higher than that of the non-flooded (Grikštaičiai and Jurjonai) and flooded (Tulkiaragè and Šyša-1) meadows, respectively. A strong linear correlation $\left(r=0.995^{* *}\right)$ was established between energy potential of sward and dry matter yield. Dry matter yield of swards determined metabolizable energy content by $99 \%$. 
The value of one or another energy process depends on the type of raw material used and its preparation costs (Tilvikienè, 2012). Bioenergy production from the herbage grown in the habitats of semi-natural or relatively natural meadows does not require a large share of the direct energy input (direct energy input for ploughing, cultivation, sowing, fertilization), the energy input is restricted to only biomass harvesting and preparation. The costs of these technological operations depend on the size of the land area, configuration and capacities of the machinery used. Transportation (fuel and energy costs) accounts for quite large portion of the costs, therefore factories of biofuel pellets should be at a relatively short distance from the growing site.
In summary of the data on swards energy potential and costs of herbage preparation for biofuel (Table 3), we can maintain that the energy value of meadow swards depended on the habitat's ecological conditions that form different habitations. The highest energy content $\left(141.03 \mathrm{GJ} \mathrm{ha}^{-1}\right)$ can be generated from the flooded meadow, situated in the central part of the Nemunas delta (Šyša-2). Similar contents of the final energy were established for other meadows, ranking in the following order: the riverside part of the Nemunas delta (Tulkiaragè) - 89.01GJ ha-1, non-flooded meadow present in the lower terrain of undulating relief (Grikštaičiai) $77.56 \mathrm{GJ} \mathrm{ha}^{-1}$, pre-land part of the Nemunas delta (Šyša-1) $-62.88 \mathrm{GJ}^{-1} \mathrm{ha}^{-1}$, non-flooded meadow present in the higher terrain of undulating relief (Jurjonai) - $57.93 \mathrm{GJ} \mathrm{ha}^{-1}$.

Table 3. Net calorific value of dry matter of meadows and energy potential of swards Data averaged over the period 2009-2012

\begin{tabular}{|c|c|c|c|c|c|}
\hline \multirow{2}{*}{ Meadow } & \multicolumn{2}{|c|}{ Net calorific value } & \multicolumn{2}{|c|}{ Energy potential of swards } & \multirow{2}{*}{$\begin{array}{c}\text { Final energy content } \\
\text { GJ ha }\end{array}$} \\
\hline & $\mathrm{MJ} \mathrm{kg}^{-1}$ & $\mathrm{CV} \%$ & GJ ha-1 & $\mathrm{CV} \%$ & \\
\hline Jurjonai & $16.74 \pm 0.22$ & 2.62 & $60.73 \pm 3.83$ & 12.6 & 57.93 \\
\hline Grikštaičiai & $16.88 \pm 0.16$ & 1.87 & $80.36 \pm 5.18$ & 12.9 & 77.56 \\
\hline Tulkiaragè & $16.76 \pm 0.10$ & 1.20 & $91.81 \pm 15.38$ & 33.5 & 89.01 \\
\hline Šyša-1 & $16.67 \pm 0.17$ & 2.03 & $65.68 \pm 11.13$ & 33.9 & 62.88 \\
\hline ŠSyša-2 & $16.63 \pm 0.12$ & 1.47 & $143.83 * * \pm 13.35$ & 18.6 & 141.03 \\
\hline Average of the experiment & 16.74 & & 88.48 & & \\
\hline $\mathrm{LSD}_{05}$ & 0.239 & & 18.849 & & \\
\hline
\end{tabular}

\section{Conclusions}

1. The phytocenoses that had formed in various habitats differed in productivity. The average dry matter yield of the non-flooded meadows was $4.19 \mathrm{t} \mathrm{ha}^{-1}$ and that of flooded meadows $6.03 \mathrm{t} \mathrm{ha}^{-1}$ (31\% higher). In all experimental years, the flooded meadow, present in the central part of the Nemunas delta stood out by a significantly higher (on average $8.64 \mathrm{t} \mathrm{ha}^{-1}$ ) dry matter yield. Of the non-flooded meadows, a higher dry matter yield (on average $4.75 \mathrm{t} \mathrm{ha}^{-1}$ ) was produced by the nonflooded meadow, exhibiting a higher humus status, present in the lower terrain of the undulating relief.

2 . The quality of the biomass of phytocenoses of the non-flooded meadows and flooded ones was similar. The biomass dry matter was found to contain 6.69-9.75\% crude protein, $23.81-25.56 \%$ crude fibre, $1.70-2.29 \%$ crude fat and $4.98-5.98 \%$ crude ash. The contents of organic carbon $\left(\mathrm{C}_{\text {org }}\right)$, total nitrogen $\left(\mathrm{N}_{\text {total }}\right)$ and sulphur (S) in the dry matter of biomass of various meadows differed little: $44.40-47.20,1.26-1.44$ and $0.12-0.16 \%$, respectively. The swards of non-flooded meadows accumulated slightly more potassium (on average $1.66 \%$ ) and those of flooded meadows accumulated more calcium (on average $0.70 \%$ ).

3 . The net calorific value of grasses of different meadows varied from 16.63 to $16.88 \mathrm{MJ} \mathrm{kg}^{-1}$. The obtained differences were within the error range. The energy potential of meadow swards varied from 60.73 to $143.8 \mathrm{GJ} \mathrm{ha}^{-1}$. The energy potential of the sward of the flooded meadow, situated in the central part of the Nemunas delta was significantly higher (143.8 GJ), it accumulated 1.8-2.4 and 1.6-2.2 times more energy than other non-flooded and flooded meadows, respectively.

4. The energy value of meadow swards depended on the habitat's ecological conditions that formed different habitations and on energy costs. The greatest amount of useful energy (141.03 $\left.\mathrm{GJ} \mathrm{ha}^{-1}\right)$ was obtained from the flooded meadow, present in the central part of the Nemunas delta. Similar amounts of final energy were established for other meadows, ranking in the following order: the riverside meadow of the Nemunas delta (Tulkiaragè) 89.01 GJ ha ${ }^{-1}$, non-flooded meadow, present in the lower terrain of undulating relief (Grikštaičiai) - 77.56 $\mathrm{GJ} \mathrm{ha}^{-1}$, pre-land meadow of the Nemunas delta (Šyša-1) - 62.88 $\mathrm{GJ} \mathrm{ha}^{-1}$, non-flooded meadow, present in the higher terrain of undulating relief (Jurjonai) - $57.93 \mathrm{GJ} \mathrm{ha}^{-1}$.

Received 07012013 Accepted 23092013

\section{References}

Butkute B., Paplauskienė V. 2004. Changes in the quality of some Lithuanian grasses as affected by cutting time in spring. Grassland Science in Europe, 9: 909-911

Butkute B., Paplauskienè V. 2006. Forage quality potential of perennial grasses. Zemdirbyste-Agriculture, 93 (3): 172 187 (in Lithuanian)

CEN/TC 335-WG2 N94. 2003. Final draft. European Committee for standardization, editor. Solid biofuels-fuel specifications and classes. Brussels, Belgium

Directive 2000/76/EC of the European Parliament and of the Council on the incineration of waste. 2000. European Commission (ed.). Official Journal of the European Communities, L 332: 91-111

Fang S., Zhai X., Wan J., Tang L. 2013. Clonal variation in growth, chemistry and calorific value of new poplar hybrids at nursery stage. Biomass and Bioenergy, 54:303$311 \mathrm{http}: / /$ dx.doi.org/10.1016/j.biombioe.2012.10.005

Hasselmann H., Bergmann H. 2007. Meadow and its economic use as a renewable energy resource in biogas plants. Grassland Science in Europe, 12: 572-575

Hensgen F., Bühle L., Donnison I., Frasier M., Vale J., Corton J., Heinsoo K., Melts I., Wachendorf M. 2012. Mineral concentrations in solid fuels from European semi-natural meadows after hydrothermal conditioning and subsequent mechanical dehydration. Bioresource Technology. 118: 332-342 http://dx.doi.org/10.1016/j.biortech.2012.05.035

Jasinskas A., Zvicevičius E. 2008. Biomasès gamybos inžinerija. Lithuanian University of Agriculture, 98 p. (in Lithuanian)

Khalsa J. H. A. 2013. Effects of plant diversity on bioenergy parameters in meadow biomass: doctoral thesis, University of Kassel. Witzenhausen, Germany

Kryževičienė A., Žaltauskas A., Jasinskas A. 2005. Cultivation and utilization of the perennial grasses as biofuel. Žemès ūkio mokslai, 1: 40-49 (in Lithuanian)

LST CEN/TS 14961-1:2010. Kietasis biokuras. Kuro techniniai reikalavimai ir klasės. 1 dalis. Bendrieji reikalavimai (in Lithuanian) 
Malat'ák J., Passian L. 2011. Heat-emission analysis of small combustion equipment for biomass. Research in Agricultural Engineering, 57: 37-50

McKendry P. 2002. Energy production from biomass (part 1): overview of hiomass. Bioresource Technology. 83: 37-46 http://dx.doi.org/10.1016/S0960-8524(01)00118-3

Obernberger I. 1998. Decentralized biomass combustion: state of the art and future development. Biomass and Bioenergy, 14: $33-56$

http://dx.doi.org/10.1016/S0961-9534(97)00034-2

Obernberger I., Brunner T., Bärnthaler G. 2006. Chemical properties of solid biofuels - significance and impact. Biomass and Bioenergy, 30: 973-982 http://dx.doi.org/10.1016/j.biombioe.2006.06.011

Orosz S., Szücsné-Péter J., Owens V., Bellus Z. 2008. Recent developments in harvesting and conservation technology for feed and biomass production of perennial forage crops. Grassland Science in Europe, 13: 529-548

Richter F. 2010. Impact of sward type, cutting date and conditioning temperature on mass and energy flows in the integrated generation of solid fuel and biogas from seminatural meadow: doctoral thesis, University of Kassel. Witzenhausen, Germany

Richter F., Fricke T., Wachendorf M. 2010. Influence of cutting date and pre-conditioning on the energy production from meadow through the integrated generation of solid fuel and biogas from biomass (IFBB). Grassland Science in Europe, 15: 172-174

Scholz V., Berg W. 1998. Energetic use of the production of biofuels. Field technologies and environment: proceedings of the international conference. Lithuanian Institute of Agricultural Engineering, p. 143-149

Siaudinis G. 2010. The investigations of perennial plants for bioenergy purposes in Western Lithuania. Modern problems and ways of their solution in science, transport, production and education'2010: proceedings of the international conference. Odessa, Ukraine, 32: 76-79

Tallowin J. R. B., Jefferson R. G. 1999. Hay production from lowland semi-natural meadows: a review of implications for ruminant livestock svstems. Grass Forage Science, 54: 99-115 http://dx.doi.org/10.1046/j.1365-2494.1999.00171.x

Tarakanovas P., Raudonius S. 2003. Statistical analysis of agronomic research data using software ANOVA, STAT, SPLIT-PLOT from the package SELEKCIJA and IRRISTAT. Lithuanian University of Agriculture (in Lithuanian)

Thumm U., Tonn B. 2010. Effect of precipitation on dry matter production of a meadow with varied cutting frequency. Grassland Science in Europe, 15: 90-92

Tilvikiené V. 2012. Management of tall fescue, cocksfoot and reed canary grass swards for biogas, biomass quality and energy value: doctoral thesis. Aleksandras Stulginskis University, Lithuanian Research Centre for Agriculture and Forestry

Tonn B., Thumm U., Claupein W. 2008. Suitability of low-intensity meadow for combustion as influenced by meadow community and harvest date. Grassland Science in Europe, 13: 751-753

Tonn B., Thumm U., Claupein W. 2010. Potential of leaching to optimise fuel quality of semi-natural meadow biomass. Grassland Science in Europe, 15: 307-309

Wachendorf M., Richter F., Fricke T., Graß R., Neff R. 2009. Utilization of seminatural meadow through integrated generation of solid fuel and biogas from biomass. I. Effects of hydrothermal conditioning and mechanical dehydration on mass flows of organic and mineral plant compounds, and nutrient balances. Grass Forage Science, 64: 132-143 http://dx.doi.org/10.1111/j.1365-2494.2009.00677.x

Апените Р. О., Латвиетис Я. Я. 1983. Пастбищная трава и подкормка коров. Рига, Латвия, с. 74-114, 177-184 (in Russian)

ISSN 1392-3196 / e-ISSN 2335-8947

Zemdirbyste-Agriculture, vol. 100, No. 4 (2013), p. 349-354

DOI 10.13080/z-a.2013.100.044

\title{
Pievų fitocenozių produktyvumo ir žolių kokybės įtaka jų biomasès energinei vertei
}

\author{
R. Skuodienè $\dot{1}^{1}$, R. Repšienè ${ }^{1}$, D. Karčauskienè $\dot{1}^{1}$, K. Katutis ${ }^{1}$, E. Sendžikienè ${ }^{2}$ \\ ${ }^{1}$ Lietuvos agrarinių ir miškų mokslų centro Vèžaičių filialas \\ ${ }^{2}$ Aleksandro Stulginskio universitetas
}

\section{Santrauka}

Lietuvoje pievų būklè nėra gera, jos yra apleistos (nešienaujamos, neganomos). Šie pokyčiai naudojant pievas turi neigiamų pasekmių, pavyzdžiui, didèja nenaudojamų žalienų plotai, kraštovaizdis tampa laukinis, o tai reiškia, kad mažèja jų ekologinè vertè.

Tyrimai atlikti 2009-2012 m. penkiose augavietėse, iš kurių dvi yra sausminès sąlygiškai apleistos pievos skirtingose banguoto reljefo vietose ir trys užliejamos pievos, esančios pavaginèje, centrinèje bei priežemyninèje Nemuno deltos dalyje. Tyrimų tikslas - palyginti sausminių ir užliejamų pievų fitocenozių produktyvumo bei kokybės ịtaką jų biomasės energinei vertei. Pievų žolynų produktyvumas ir energinè vertè priklauso nuo augavietės ekologinių sąlygų, kurios formuoja skirtingas buveines. Sausminių pievų vidutinis sausujų medžiagų kiekis buvo 4,19 $\mathrm{t} \mathrm{ha}^{-1}$, o užliejamų pievų - 6,03 $\mathrm{t} \mathrm{ha}^{-1}$, arba $31 \%$ didesnis. Skirtingose augavietèse susiformavusių fitocenoziu biomasès kokybè buvo panaši. Sausosiose medžiagose nustatyta 6,69-9,75\% žaliu baltymų, 23,81-25,56\% žalios ląstelienos, 1,70-2,29 \% žalių riebalų ir 4,98-5,98 \% žalių pelenų, 44,40-47,20 \% organinès anglies, 1,26$1,44 \%$ suminio azoto, $0,12-0,16 \%$ sieros. Sausminių pievų žolynai šiek tiek daugiau sukaupe kalio (vidutiniškai $1,66 \%$ ), o užliejamos pievos - kalcio (vidutiniškai 0,70 \%). Skirtingų pievų žolių grynasis šilumingumas kito nuo 16,63 iki 16,88 $\mathrm{MJ} \mathrm{kg}^{-1}$, o energinis potencialas - nuo 60,73 iki 143,8 $\mathrm{GJ}^{-1}$. Užliejamos pievos, esančios centrinėje Nemuno deltos dalyje, žolyno energinis potencialas buvo iš esmès didesnis (143,8 GJ), arba sukaupė 1,8-2,4 ir 1,6-2,2 karto daugiau energijos nei sausminès ir kitos užliejamos pievos. Tirtų pievų žolių paruošimo ir transportavimo energijos sąnaudos sudare $2,8 \mathrm{GJ} \mathrm{ha}^{-1}$. Daugiausia naudingos energijos $\left(141,03 \mathrm{GJ}^{-1}\right)$ buvo gauta iš užliejamos pievos, esančios centrinejje Nemuno deltos dalyje. Kitų pievų galutinès energijos kiekis nustatytas panašus ir buvo toks: pavaginès Nemuno deltos pievos $-89,01 \mathrm{GJ} \mathrm{ha}^{-1}$, sausminès pievos, esančios žemesneje banguoto reljefo vietoje - 77,56 GJ ha ${ }^{-1}$, priežemyninès Nemuno deltos pievos $-62,88 \mathrm{GJ} \mathrm{ha}^{-1}$, sausminès pievos, esančios aukštesneje banguoto reljefo vietoje $-57,93 \mathrm{GJ}^{-1} \mathrm{ha}^{-1}$.

Reikšminiai žodžiai: ekologinès sąlygos, energinè vertė, pievų fitocenozės, produktyvumas, žolynų kokybė. 